\title{
The experience of pain among patients living with Hepatitis C: an assessment of prevalence and needs
}

\author{
Christine Cabrera ${ }^{1 *}$, Kimberly Corace ${ }^{2}$, Louise Balfour ${ }^{2}$, George Tasca² ${ }^{2}$ Curtis Cooper ${ }^{2}$, Jonathan Angel ${ }^{2}$, \\ William Cameron², Paul MacPherson², Gary Garber ${ }^{2}$
}

From $16^{\text {th }}$ International Symposium on HIV and Emerging Infectious Diseases

Marseille, France. 24-26 March 2010

\section{Background}

It is estimated that 300,000 individuals in Canada are infected with Hepatitis $\mathrm{C}(\mathrm{HCV})$. The pain experiences reported in relation to $\mathrm{HCV}$ appear to vary highly in both prevalence and source. Experiences of pain/pain treatment can be complicated by feelings of depression and poor sleep; whereby, pain can contribute to both depression and poorer sleep. This study will assess the prevalence and impact of pain among $\mathrm{HCV}$ patients from The Ottawa Hospital $(\mathrm{TOH})$ including patient interest in various pain treatment options.

\section{Methods}

A questionnaire study was conducted among $\mathrm{HCV}$ patients seen at the Viral Hepatitis Clinic at TOH between June-December 2008. The questionnaire package contained: Socio-demographics, CES-Depression Scale, Sleep Impairment Index, and Pain Treatment Preferences.

\section{Results}

$128 \mathrm{HCV}$ patients met eligibility criteria for the study; 91 (71\%) completed the survey. 56\% of HCV patients reported chronic pain which commonly affected their back, legs, and joints. A majority (91\%) reported that they would feel comfortable telling their healthcare providers about their pain. $\mathrm{HCV}$ patients with pain expressed a preference for visiting their family doctor and $\mathrm{HCV}$ specialist for pain treatment; almost half (47\%) were interested in group-based pain management. Also, HCV patients with chronic pain reported significantly poorer sleep and greater feelings of depression.

\footnotetext{
* Correspondence: ccabr092@uottawa.ca
}

${ }^{1}$ University of Ottawa, Ottawa, Canada

\section{Discussion}

Overall, pain is a significant treatment concern in this sample of HCV patients. These results suggest that it may be important to consider incorporating pain assessment procedures into routine clinical care for $\mathrm{HCV}$ patients. The timely assessment/treatment of pain among HCV patients may also be facilitated by the development of standardized clinical tools and by providing information to healthcare workers on available options for treating chronic pain including non-pharmacological psycho-educational pain management.

\section{Author details}

${ }^{1}$ University of Ottawa, Ottawa, Canada. ${ }^{2}$ The Ottawa Hospital-General

Campus, Ottawa, Canada.

Published: 11 May 2010

doi:10.1186/1742-4690-7-S1-P85

Cite this article as: Cabrera et al:: The experience of pain among patients living with Hepatitis C: an assessment of prevalence and needs. Retrovirology 2010 7(Suppl 1):P85.

Submit your next manuscript to BioMed Central and take full advantage of:

- Convenient online submission

- Thorough peer review

- No space constraints or color figure charges

- Immediate publication on acceptance

- Inclusion in PubMed, CAS, Scopus and Google Scholar

- Research which is freely available for redistribution

Submit your manuscript at www.biomedcentral.com/submit
Biomed Central 